\title{
Synthesis and Study of New N-Substituted Hydrazones of Ni(II) Complexes of $\beta$-Octaethylporphyrin and Coproporphyrin I Tetraethyl Ester
}

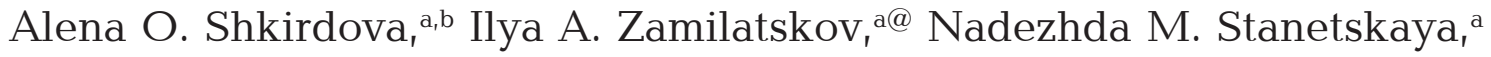 \\ Victor A. Tafeenko, ${ }^{c}$ Vladimir S. Tyurin, ${ }^{a}$ Vladimir V. Chernyshev, ${ }^{\mathrm{a}, \mathrm{c}}$ \\ Gelii V. Ponomarev, ${ }^{\mathrm{d}}$ and Aslan Yu. Tsivadze
}

\author{
a A.N. Frumkin Institute of Physical Chemistry and Electrochemistry of the Russian Academy of Sciences, 119071 Moscow, \\ Russian Federation \\ ${ }^{\mathrm{b}}$ Moscow Technological University, Institute of Fine Chemical Technologies, 119571 Moscow, Russian Federation \\ ${ }^{c}$ Chemical Department, Moscow State University, 119899 Moscow, Russian Federation \\ ${ }^{\mathrm{d}}$ Research Institute of Biomedical Chemistry, 119121 Moscow, Russian Federation \\ ${ }^{\circledR}$ Corresponding authorE-mail: joz@mail.ru
}

\begin{abstract}
$N$-Substituted hydrazones of nickel complexes of $\beta$-octaethylporphyrin and tetraethyl ester of coproporphyrin I were obtained. These compounds can serve as intermediate compounds for the preparation of meso-functionalized derivatives of porphyrins by means of various reactions. In the first stage Vilsmeier-Haack reaction was carried out by the interaction of nickel complexes of $\beta$-octaethylporphyrin and tetraethyl ester of coproporphyrin I with $N, N$-dimethylformamide and phosphorus(V) oxochloride forming the so-called "phosphorus complex", which was hydrolyzed with saturated solution of sodium acetate. The corresponding meso-formyl derivatives of metal porphyrins were obtained as a result. Synthesis of the hydrazones was carried out by the reactions of meso-formyl derivatives with the hydrazines using trifluoroacetic acid as a catalyst. The result of the reaction was formation of hydrazones in the form of a mixture of E-and Z-isomers, which were separated using preparative thin layer chromatography. Thus a series of hydrazones with different substituents at the nitrogen atom was obtained. The structures of all obtained compounds were determined using the methods of NMR spectroscopy, electronic absorption spectroscopy and mass spectrometry. For nickel complex of tosylhydrazone derivative of $\beta$-octaethylporphyrin the crystal structure was determined using X-ray diffraction. X-ray analysis shows that porphyrin molecules in the crystal form dimers bonded by two hydrogen bonds between the hydrogen atom of the NH-group of hydrazone and the oxygen atom of the sulfonate groups.
\end{abstract}

Keywords: Octaethylporphyrin, coproporphyrin, porphyrin hydrazones, nickel complexes, Vilsmeier-Haack reaction.

\section{Introduction}

Porphyrins and their structural analogues are a vital chemical unit, they are necessary for numerous biologically significant processes, such as photosynthesis, transportation and storage of oxygen in tissues of living organisms. Porphyrins and metalloporphyrins are widely distributed in nature, the aromatic system of porphyrin bonds makes them very promising for use in various fields of science and technology. Due to their unique photophysical and photochemical properties, porphyrins and metalloporphyrins are used as various sensors in bioanalysis, ${ }^{[1,2]}$ active substances of drugs in the diagnosis and therapy of cancer. ${ }^{[3]}$

The fundamental task, addressed by numerous studies in the fields of bioorganic and medical chemistry, is the creation of new drugs based on porphyrin conjugates with vari- ous biologically active compounds and other functional fragments, ${ }^{[4-7]}$ having specified properties, such as low toxicity, hydrophilicity, high selectivity of accumulation and distribution in affected cells and tissues. Palladium-catalyzed cross-coupling reactions are widely used to produce various functionalized derivatives of mono- and oligoporphyrins, which possess practically useful properties. ${ }^{[8-10]}$ Most of such reactions are associated with the combination of halogenated porphyrins with various reagents. At the same time, the preparation of mono-meso-halogenated derivatives of $\beta$-alkyl substituted porphyrins is not an easy task. Reactions of mesoformyl derivatives of porphyrins can serve as alternative approach to the preparation of meso-functionalized derivatives.

Earlier, we obtained azomethine derivatives of palladium complexes of $\beta$-octaethylporphyrin and coproporphyrin $I,{ }^{[11-13]}$ as well as ruthenium complexes of coproporphy- 


\title{
Синтез и исследование новых $N$-замещенных гидразонов $\mathrm{Ni}(\mathrm{II})$ комплексов $\beta$-октаэтилпорфирина и тетраэтилового эфира копропорфирина I
}

\author{
А. О. Шкирдова, ${ }^{\text {a,b }}$ И. А. Замилацков, ${ }^{a}{ }^{@}$ Н. М. Станецкая, ${ }^{a}$ В. А. Тафреенко, ${ }^{c}$ \\ В. С. Тюрин, ${ }^{a}$ В. В. Чернышев, ${ }^{\text {a,c }}$ Г. В. Пономарев, ${ }^{\mathrm{d}}$ А. Ю. Цивадзе ${ }^{\mathrm{a}}$ \\ а Институт физической химии и электрохимии имени А.Н. Фрумкина РАН, 119071 Москва, Россия \\ ${ }^{\mathrm{b}}$ Московский технологический университет, Институт тонких химических технологий, 119571 Москва, Россия \\ ${ }^{\mathrm{c}}$ Московский государственный университет имени М.В. Ломоносова, Химический факультет, 119991 Москва, Россия \\ ${ }^{\mathrm{d}}$ Научно-исследовательский институт биомедицинской химии имени В.Н. Ореховича, 119121 Москва, Россия \\ @E-mail: joz@mail.ru
}

\begin{abstract}
Были получены $N$-замещенные гидразоны никелевых комплексов $\beta$-октаэтилпорфирина и тетраэтилового эфира копропорфирина I. Такие соединения могут быть использовань для получения мезо-функиионализированных производных порфиринов при помощи различных реакичй. На первом этапе по реакции Вильсмейера-Хаака путем взаимодействия никелевых комплексов $\beta$-октаэтилпорфирина и тетраэтилового эфира копропорфирина Ic $N, N$-диметилформамидом и оксохлоридом фосфора $(V)$ образовался так называемый «фосфорный комплекс», который гидролизовали насыщенным раствором ацетата натрия. В результате были получены соответствующче мезо-формилпроизводные металлопорфиринов. Синтез гидразонов проводили путем реакиии полученных мезо-формилпроизводных с гидразинами, используя трифторуксусную кислоту в качестве катализатора. В результате реакции происходило образование гидразонов в виде смеси E- и Z-изомеров, которые разделяли при помощи препаративной тонкослойной хроматографии. Таким образом был получен ряд гидразонов с различными заместителями у атома азота. Строение всех полученных соединений установлено с помощьью методов ЯМР спектроскопии, электронной спектроскопии поглощения, а также масс-спектрометрии. Для никелевого комплекса тозилгидразонового производного $\beta$-октаэтилпорфирина установлена структура при помощи рентгеноструктурного анализа. Обнаружено, что молекуль в кристалле образуют димеры, связаннье двумя водородными связями между атомами водорода NH-группь гидразона и атомом кислорода сульфогруппы.
\end{abstract}

Ключевые слова: Октаэтилпорфирин, копропорфирин, порфириновые гидразоны, комплексы никеля, реакция Вильсмейера-Хаака.

rin $\mathrm{I}^{[14,15]}$ The reaction between pyropheophorbide $a$ methyl ester and hydrazine hydrate has been studied and the optimal conditions for the selective synthesis of corresponding hydrazones and azines have been found. In continuation of the work on meso-fuctionalized porphyrins we carried out the synthesis of previously unknown $N$-substituted hydrazones of $\mathrm{Ni}$ (II) complexes of $\beta$-octaethylporphyrin and tetraethyl ester of coproporphyrin I. ${ }^{[16]}$ Such porphyrins can be precursors of the variety of meso-functionalized porphyrins including meso-(2-iodvinyl)porphyrins ${ }^{[17]}$ being a convenient substrate for the synthesis of porphyrin conjugates via catalytic cross-coupling reactions.

\section{Experimental}

\section{Measurements}

UV-Vis electronic absorption spectra were registered using U-2900 (Hitachi) spectrophotometer and quartz rectangular cells of $1-10 \mathrm{~mm}$ path length. ${ }^{1} \mathrm{H}(600 \mathrm{MHz}) \mathrm{NMR}$ spectra were recorded at $\mathrm{T}=298 \mathrm{~K}$ with a Bruker Avance III 600 spectrometer in $\mathrm{CDCl}_{3}$. Chemical shifts $\delta$ are quoted in parts per million (ppm) downfield of tetramethylsilane. Coupling constants are given in $\mathrm{Hz} .{ }^{13} \mathrm{C}(150$ or $75 \mathrm{MHz}$ ) NMR spectra were recorded on a Bruker Avance III 600 or Bruker AVANCE I 300 in $\mathrm{CDCl}_{3}$, respectively. The LDITOF mass-spectra were obtained on a Ultraflex-II mass spectrometer (Bruker Daltonics) in a positive ion mode using reflection mode ( $20 \mathrm{mV}$ target voltage) without matrix. The $\mathrm{m} / \mathrm{z}$ values are given for the major isotope of nickel (Ni-58).

\section{Materials}

All commercial reagents were purchased and used without further purification. Solvents were purified by standard procedures: $\mathrm{CH}_{2} \mathrm{Cl}_{2}$ and 1,2-dichloroethane were distilled over calcium hydride under argon.

All reactions were performed under protection from direct light under argon and monitored using electronic absorption spectroscopy and by TLC Macherey-Nagel Alugram SIL G/UV254 silica gel 60 UV254. Silica gel 40/60 (Merck) was used for column and flash chromatography. Silica gel 60 (Merck) at $20 \times 20 \mathrm{~cm}$ plates with a layer thickness of $1 \mathrm{~mm}$ was used for preparative TLC. A mixture of solvents: methylene chloride - methanol was used as an eluent.

\section{Synthesis}

The coproporphyrin I was obtained according to the method described by K. Smith. ${ }^{[18]} \beta$-Octaethylporphyrin was obtained 
by monopyrrole condensation described by Johnson. ${ }^{[19]} \mathrm{Ni}(\mathrm{II})$ complexes of coproporphyrin I tetraethyl ester and $\beta$-octaethylporphyrin were prepared according to procedure described by K. Smith. ${ }^{[20]}$

A typical procedure for synthesis of Ni(II) formyl derivatives of porphyrins. To a solution of $\mathrm{Ni}$ (II) porphyrin complex $(0.073$ $\mathrm{mmol}$ ) in $10 \mathrm{ml}$ of dry 1,2-dichloroethane the Vilsmeier reagent, in situ formed from $\mathrm{POCl}_{3}(1.5 \mathrm{ml}, 21.5 \mathrm{mmol})$ and $N, N$-dimethylformamide $(1.5 \mathrm{ml}, 25.9 \mathrm{mmol})$, was added at $60^{\circ} \mathrm{C}$. The resulting mixture was stirred for 2 hours at the same temperature and the reaction was monitored by TLC $\left(\mathrm{CH}_{2} \mathrm{Cl}_{2}: \mathrm{MeOH}=100: 4\right)$. Then the solvent was evaporated in vacuum and the residue obtained was dissolved in $\mathrm{CH}_{2} \mathrm{Cl}_{2}(50 \mathrm{ml})$ and washed with $\mathrm{H}_{2} \mathrm{O}(50 \mathrm{ml})$ then 20 $\mathrm{ml}$ of saturated solution of sodium acetate was added and stirred at $50{ }^{\circ} \mathrm{C}$ for $2 \mathrm{hrs}$ monitoring by TLC. After that the organic layer was separated, washed by water $(2 \times 10 \mathrm{ml})$, dried with sodium sulfate and the solvent was evaporated in vacuum and the residue was purified by column chromatography (silica gel) with eluent $\mathrm{CH}_{2} \mathrm{Cl}_{2}: \mathrm{MeOH}=100: 1$ to afford the $\mathrm{Ni}(\mathrm{II})$ complex of meso-formyl substituted porphyrins.

$\mathrm{Ni}$ (II) complex of meso-formylcoproporphyrin I tetraethyl ester (7). Yield $78 \%$. LDI-TOF MS $m / z$ : 851.6. Calcd. for $[\mathrm{M}+\mathrm{H}]^{+}$851.3. UV-Vis $\lambda_{\text {max }}\left(\mathrm{CHCl}_{3}\right) \mathrm{nm}: 401,423,560,645 .{ }^{1} \mathrm{H}$ $\operatorname{NMR}\left(\mathrm{CDCl}_{3}, 278 \mathrm{~K}\right) \delta_{\mathrm{H}} \mathrm{ppm}: 1.17-1.18\left(6 \mathrm{H}, \mathrm{m}, \mathrm{OCH}_{2} \mathrm{CH}_{3}\right), 1.21$ $\left(3 \mathrm{H}, \mathrm{t},{ }^{3} \mathrm{~J}=7.25, \mathrm{OCH}_{2} \mathrm{CH}_{3}\right), 1.32\left(3 \mathrm{H}, \mathrm{t},{ }^{3} \mathrm{~J}=7.26, \mathrm{OCH}_{2} \mathrm{CH}_{3}\right), 2.84$ $-3.11\left(8 \mathrm{H}, \mathrm{m}, \beta-\mathrm{CH}_{2}\right), 3.10\left(3 \mathrm{H}, \mathrm{s}, \beta-\mathrm{CH}_{3}\right), 3.35\left(3 \mathrm{H}, \mathrm{s}, \beta-\mathrm{CH}_{3}\right)$, $3.41\left(6 \mathrm{H}, \mathrm{s}, \beta-\mathrm{CH}_{3}\right), 3.95\left(2 \mathrm{H}, \mathrm{q},{ }^{3} \mathrm{~J}=7.90, \beta-\mathrm{CH}_{2}\right), 4.14-4.27(14 \mathrm{H}$, $\left.\mathrm{m}, \mathrm{OCH}_{2} \mathrm{CH}_{3}+\beta-\mathrm{CH}_{2}\right), 9.55(1 \mathrm{H}, \mathrm{s}, 15 \mathrm{CH}), 9.56(2 \mathrm{H}, \mathrm{s}, 5,20 \mathrm{CH})$, $10.71(1 \mathrm{H}, \mathrm{s}, \mathrm{CH}$ in $\mathrm{CH}=\mathrm{O})$.

$\mathrm{Ni}(\mathrm{II})$ complex of meso-formyl- $\beta$-octaethylporphyrin (2). Yield $74 \%$. LDI-TOF MS m/z: 619.5. Calcd. for $[\mathrm{M}+\mathrm{H}]^{+} 619.3$. $\mathrm{UV}-\mathrm{Vis} \lambda_{\text {max }}\left(\mathrm{CHCl}_{3}\right) \mathrm{nm}: 402,423,526,561,652 .{ }^{1} \mathrm{H} \mathrm{NMR}\left(\mathrm{CDCl}_{3}\right.$, $278 \mathrm{~K}) \delta_{\mathrm{H}}$ ppm: $1.69-1.79\left(24 \mathrm{H}, \mathrm{m}, \mathrm{CH}_{2} \mathrm{CH}_{3}\right), 3.73-3.81(16 \mathrm{H}, \mathrm{m}$, $\left.\mathrm{CH}_{2} \mathrm{CH}_{3}\right), 9.33(2 \mathrm{H}, \mathrm{s}, 5,20 \mathrm{CH}), 9.36(1 \mathrm{H}, \mathrm{s}, 15 \mathrm{CH}), 11.92(1 \mathrm{H}$, $\mathrm{s}, \mathrm{CH}=\mathrm{O}$ ). The spectra correspond to the published data within the limits of insignificant deviations. ${ }^{[21]}$

A typical procedure for synthesis of $\mathrm{Ni}(\mathrm{II})$ hydrazone derivatives of porphyrins 3-5, 9. To a solution of $\mathrm{Ni}$ (II) complex of mesoformylporphyrins $(\mathbf{2}$ or 7$)(0.05 \mathrm{mmol})$ in $16 \mathrm{ml}$ of dry dichloromethane $p$-tosylhydrazine $(0.05 \mathrm{mmol})$ and trifluoroacetic acid $(0.05 \mathrm{mmol})$ were added. The resulting mixture was stirred for 4 hours at $45^{\circ} \mathrm{C}$ monitoring by TLC $\left(\mathrm{CH}_{2} \mathrm{Cl}_{2}: \mathrm{MeOH}=100: 4\right)$. Then the solvent was evaporated in vacuum and the residue was purified by column chromatography (silica gel) with eluent $\mathrm{CH}_{2} \mathrm{Cl}_{2}$ to afford a mixture of $E$ - and $Z$-isomers of $\mathrm{Ni}(\mathrm{II})$ complexes of meso-hydrazone derivatives of porphyrins.

$\mathrm{Ni}$ (II) complex of meso-hydrazone derivative of $\beta$-octaethylporphyrin (3). Yield $58 \%$. LDI-TOF MS $m / z$ : 633.5. Calcd. for $[\mathrm{M}+\mathrm{H}]^{+}$633.3. UV-Vis $\lambda_{\text {max }}\left(\mathrm{CHCl}_{3}\right) \mathrm{nm}: 401,526,562 .{ }^{1} \mathrm{H} \mathrm{NMR}$ $\left(\mathrm{CDCl}_{3}, 278 \mathrm{~K}\right) \delta_{\mathrm{H}} \mathrm{ppm}: 1.63\left(6 \mathrm{H}, \mathrm{t},{ }^{3} \mathrm{~J}=7.42, \mathrm{CH}_{2} \mathrm{CH}_{3}\right), 1.74(6 \mathrm{H}$, $\left.\mathrm{t},{ }^{3} \mathrm{~J}=7.63, \mathrm{CH}_{2} \mathrm{CH}_{3}\right), 1.78\left(12 \mathrm{H}, \mathrm{t},{ }^{3} \mathrm{~J}=7.78, \mathrm{CH}_{2} \mathrm{CH}_{3}\right), 2.23(2 \mathrm{H}, \mathrm{s}$, $\left.\mathrm{NH}_{2}\right), 3.73-3.78\left(4 \mathrm{H}, \mathrm{m}, \mathrm{CH}_{2} \mathrm{CH}_{3}\right), 3.82-3.87\left(12 \mathrm{H}, \mathrm{m}, \mathrm{CH}_{2} \mathrm{CH}_{3}\right)$, $9.51(1 \mathrm{H}, \mathrm{s}, 15 \mathrm{CH}), 9.52(2 \mathrm{H}, \mathrm{s}, 5,20 \mathrm{CH}), 10.87(1 \mathrm{H}, \mathrm{s}, \mathrm{CH}=\mathrm{N})$.

Z-isomer of the Ni(II) complex of meso-tosylhydrazone derivative of $\beta$-octaethylporphyrin (4a). Yield $64 \%$. LDI-TOF MS $m / z$ : 787.2. Calcd. for $[\mathrm{M}+\mathrm{H}]^{+}$787.3. UV-Vis $\lambda_{\text {max }}\left(\mathrm{CHCl}_{3}\right)$ $\mathrm{nm}: 401,527,565 .{ }^{1} \mathrm{H} \mathrm{NMR}\left(\mathrm{CDCl}_{3}, 278 \mathrm{~K}\right) \delta_{\mathrm{H}} \mathrm{ppm}: 1.54(6 \mathrm{H}$, t, $\left.{ }^{3} \mathrm{~J}=7.42, \mathrm{CH}_{2} \mathrm{CH}_{3}\right), 1.76\left(6 \mathrm{H}, \mathrm{t},{ }^{3} \mathrm{~J}=7.73, \mathrm{CH}_{2} \mathrm{CH}_{3}\right), 1.84(6 \mathrm{H}, \mathrm{t}$, $\left.{ }^{3} \mathrm{~J}=7.52, \mathrm{CH}_{2} \mathrm{CH}_{3}\right), 1.85\left(6 \mathrm{H}, \mathrm{t},{ }^{3} \mathrm{~J}=7.49, \mathrm{CH}_{2} \mathrm{CH}_{3}\right), 2.46(3 \mathrm{H}, \mathrm{s}$, $\left.\mathrm{CH}_{3}(\mathrm{Tos})\right), 3.54\left(2 \mathrm{H}, \mathrm{m}, \mathrm{CH}_{2} \mathrm{CH}_{3}\right), 3.68\left(2 \mathrm{H}, \mathrm{m}, \mathrm{CH}_{2} \mathrm{CH}_{3}\right), 3.77$ $\left(2 \mathrm{H}, \mathrm{m}, \mathrm{CH}_{2} \mathrm{CH}_{3}\right), 3.92\left(10 \mathrm{H}, \mathrm{m}, \mathrm{CH}_{2} \mathrm{CH}_{3}\right), 6.03(1 \mathrm{H}, \mathrm{s}, \mathrm{NH})$, 7.17-7.19 (2H, m, AA' part of AA'XX' spin system, $\mathrm{C}_{(2)} \mathrm{H}^{\prime}$ and $\mathrm{C}_{(6)} \mathrm{H}$ in 4- $\left.\mathrm{MeC}_{6} \mathrm{H}_{4}\right), 7.39-7.40\left(2 \mathrm{H}, \mathrm{m}, \mathrm{XX}^{\prime}\right.$ part of $\mathrm{AA}^{\prime} \mathrm{XX}^{\prime}$ ' spin system, $\mathrm{C}_{(3)} \mathrm{H}$ and $\mathrm{C}_{(5)} \mathrm{H}$ in $\left.4-\mathrm{MeC}_{6} \mathrm{H}_{4}\right), 9.59(2 \mathrm{H}, \mathrm{s}, 10,20 \mathrm{CH}), 9.62(1 \mathrm{H}, \mathrm{s}$, $15 \mathrm{CH}), 9.93(1 \mathrm{H}, \mathrm{s}, \mathrm{CH}=\mathrm{N})$.

E-isomer of the Ni(II) complex of meso-tosylhydrazone derivative of $\beta$-octaethylporphyrin (4b). Yield $16 \%$. LDI-TOF MS $m / z$ : 787.2. Calcd. for $[\mathrm{M}+\mathrm{H}]^{+}$787.9. UV-Vis $\lambda$ ( $\left(\mathrm{CHCl}_{3}\right) \mathrm{nm}: 400$, 526, 566. ${ }^{1} \mathrm{H}$ NMR $\left(\mathrm{CDCl}_{3}, 278 \mathrm{~K}\right) \delta_{\mathrm{H}} \mathrm{ppm}: 1.41\left(6 \mathrm{H}, \mathrm{t},{ }^{3} \mathrm{~J}=7.68\right.$,
$\left.\mathrm{CH}_{2} \mathrm{CH}_{3}\right), 1.72\left(6 \mathrm{H}, \mathrm{t},{ }^{3} \mathrm{~J}=7.72, \mathrm{CH}_{2} \mathrm{CH}_{3}\right), 1.80\left(12 \mathrm{H}, \mathrm{t},{ }^{3} \mathrm{~J}=7.75\right.$, $\left.\mathrm{CH}_{2} \mathrm{CH}_{3}\right), 2.28\left(3 \mathrm{H}, \mathrm{s}, \mathrm{CH}_{3}(\mathrm{Tos})\right), 3.44\left(4 \mathrm{H}, \mathrm{q},{ }^{3} \mathrm{~J}=7.73, \mathrm{CH}_{2} \mathrm{CH}_{3}\right)$, $3.77\left(4 \mathrm{H}, \mathrm{q},{ }^{3} \mathrm{~J}=7.73, \mathrm{CH}_{2} \mathrm{CH}_{3}\right), 3.85\left(8 \mathrm{H}, \mathrm{q},{ }^{3} \mathrm{~J}=7.75, \mathrm{CH}_{2} \mathrm{CH}_{3}\right)$, 7.04-7.05 (2H, m, AA' part of AA' XX' spin system, $\mathrm{C}_{(2)} \mathrm{H}^{2}$ and $\mathrm{C}_{(6)}$ $\mathrm{H}$ in 4- $\left.\mathrm{MeC}_{6} \mathrm{H}_{4}\right), 7.60-7.61\left(2 \mathrm{H}, \mathrm{m}, \mathrm{XX}^{\prime}\right.$ part of AA' $\mathrm{XX}$ ' spin system, $\mathrm{C}_{(3)} \mathrm{H}$ and $\mathrm{C}_{(5)} \mathrm{H}$ in $\left.4-\mathrm{MeC}_{6} \mathrm{H}_{4}\right), 8.57(1 \mathrm{H}, \mathrm{s}, \mathrm{NH}), 9.50(2 \mathrm{H}, \mathrm{s}$, $10,20 \mathrm{CH}), 9.51(1 \mathrm{H}, \mathrm{s}, 15 \mathrm{CH}), 10.11(1 \mathrm{H}, \mathrm{s}, \mathrm{CH}=\mathrm{N})$.

$\mathrm{Ni}$ (II) complex of meso-2,4-dinitrophenylhydrazone derivative of $\beta$-octaethylporphyrin (major isomer) (5a). Yield $63 \%$. LDITOF MS $m / z$ : 799.6. Calcd. for $[\mathrm{M}+\mathrm{H}]^{+}$799.3. UV-Vis $\lambda_{\text {max }}\left(\mathrm{CHCl}_{3}\right)$ nm: 399, 527, 564. ' ${ }^{1} \mathrm{NMR}\left(\mathrm{CDCl}_{3}, 278 \mathrm{~K}\right) \delta_{\mathrm{H}} \mathrm{ppm}: 1.68(6 \mathrm{H}$, t, $\left.{ }^{3} \mathrm{~J}=7.60, \mathrm{CH}_{2} \mathrm{CH}_{3}\right), 1.73\left(6 \mathrm{H}, \mathrm{t},{ }^{3} \mathrm{~J}=7.84, \mathrm{CH}_{2} \mathrm{CH}_{3}\right), 1.81(6 \mathrm{H}, \mathrm{t}$, $\left.{ }^{3} \mathrm{~J}=7.72, \mathrm{CH}_{2} \mathrm{CH}_{3}\right), 1.85\left(6 \mathrm{H}, \mathrm{t},{ }^{3} \mathrm{~J}=7.72, \mathrm{CH}_{2} \mathrm{CH}_{3}\right), 3.77-3.95(16 \mathrm{H}$, $\left.\mathrm{m}, \mathrm{CH}_{2} \mathrm{CH}_{3}\right), 7.98-8.00\left(1 \mathrm{H}, \mathrm{m}, \mathrm{MX}\right.$ part of AMX spin system, $\mathrm{C}_{(6)}$ $\mathrm{H}$ in 2,4-dinitro $\left.\mathrm{C}_{6} \mathrm{H}_{3}\right), 8.21-8.23(1 \mathrm{H}, \mathrm{m}, \mathrm{AX}$ part of AMX spin system, $\mathrm{C}_{(5)} \mathrm{H}$ in 2,4-dinitro $\left.\mathrm{C}_{6} \mathrm{H}_{3}\right), 8.55-8.56(1 \mathrm{H}, \mathrm{m}, \mathrm{AM}$ part of AMX spin system, $\mathrm{C}_{(3)} \mathrm{H}$ in 2,4-dinitroC $\left.\mathrm{C}_{6} \mathrm{H}_{3}\right), 9.45(1 \mathrm{H}, \mathrm{s}, \mathrm{NH}), 9.60(2 \mathrm{H}$, $\mathrm{s}, 5,20 \mathrm{CH}), 9.63(1 \mathrm{H}, \mathrm{s}, 15 \mathrm{CH}), 10.21(1 \mathrm{H}, \mathrm{s}, \mathrm{CH}=\mathrm{N})$.

$\mathrm{Ni}(\mathrm{II})$ complex of meso-tosylhydrazone derivative of coproporphyrin I tetraethyl ester (major isomer) (9a). Yield $75 \%$. LDI-TOF MS $m / z$ : 1019.3. Calcd. for $[\mathrm{M}+\mathrm{H}]^{+}$1019.4. UV-Vis $\lambda_{\max }\left(\mathrm{CHCl}_{3}\right) \mathrm{nm}: 400,525,561 .{ }^{1} \mathrm{H}$ NMR $\left(\mathrm{CDCl}_{3}, 278 \mathrm{~K}\right) \delta_{\mathrm{H}} \mathrm{ppm}:$ $1.20-1.23\left(6 \mathrm{H}, \mathrm{m}, \mathrm{OCH}_{2} \mathrm{CH}_{3}\right), 1.46\left(6 \mathrm{H}, \mathrm{t},{ }^{3} \mathrm{~J}=7.16, \mathrm{OCH}_{2} \mathrm{CH}_{3}\right)$, $2.28\left(3 \mathrm{H}, \mathrm{s}, \mathrm{CH}_{3}(\mathrm{Tos})\right), 3.01-3.04\left(4 \mathrm{H}, \mathrm{m}, \beta-\mathrm{CH}_{2}\right), 3.05(3 \mathrm{H}, \mathrm{s}$, $\left.\beta-\mathrm{CH}_{3}\right), 3.09-3.14\left(4 \mathrm{H}, \mathrm{m}, \beta-\mathrm{CH}_{2}\right), 3.35\left(3 \mathrm{H}, \mathrm{s}, \beta-\mathrm{CH}_{3}\right), 3.45(6 \mathrm{H}$, $\left.\mathrm{s}, \beta-\mathrm{CH}_{3}\right), 4.11-4.22\left(14 \mathrm{H}, \mathrm{m}, \mathrm{OCH}_{2} \mathrm{CH}_{3}+\beta-\mathrm{CH}_{2}\right), 4.39(2 \mathrm{H}, \mathrm{q}$, $\left.{ }^{3} \mathrm{~J}=7.20, \mathrm{OCH}_{2} \mathrm{CH}_{3}\right), 7.00-7.02\left(2 \mathrm{H}, \mathrm{m}, \mathrm{AA}^{\prime}\right.$ part of $\mathrm{AA}^{\prime} \mathrm{XX}$ ' spin system, $\mathrm{C}_{(2)} \mathrm{H}$ and $\mathrm{C}_{(6)} \mathrm{H}$ in 4- $\left.\mathrm{MeC}_{6} \mathrm{H}_{4}\right), 7.57-7.59(2 \mathrm{H}, \mathrm{m}, \mathrm{XX}$ ' part of AA'XX' spin system, $\mathrm{C}_{(3)} \mathrm{H}$ and $\mathrm{C}_{(5)} \mathrm{H}$ in $\left.4-\mathrm{MeC}_{6} \mathrm{H}_{4}\right), 9.52(1 \mathrm{H}$, s, $\mathrm{NH}), 9.57(1 \mathrm{H}, \mathrm{s}, 15 \mathrm{CH}), 9.59(1 \mathrm{H}, \mathrm{s}, 20 \mathrm{CH}), 9.61(1 \mathrm{H}, \mathrm{s}, 5 \mathrm{CH})$, $10.23(1 \mathrm{H}, \mathrm{s}, \mathrm{CH}=\mathrm{N})$.

A one-pot procedure for synthesis of Ni(II) non-substituted hydrazone derivatives of coproporphyrin I tetraethyl ester. To a solution of $\mathrm{Ni}(\mathrm{II})$ coproporphyrin I tetraethyl ester (6) $(25 \mathrm{mg}$, $0.029 \mathrm{mmol}$ ) in $10 \mathrm{ml}$ of dry 1,2-dichloroethane the Vilsmeier reagent, in situ formed from $\mathrm{POCl}_{3}(1 \mathrm{ml}, 10.5 \mathrm{mmol})$ and $N, N$ dimethylformamide $(1 \mathrm{ml}, 13 \mathrm{mmol})$, was added at $60{ }^{\circ} \mathrm{C}$. The resulting mixture was stirred for 2 hours at the same temperature and the reaction was monitored by TLC $\left(\mathrm{CH}_{2} \mathrm{Cl}_{2}: \mathrm{MeOH}=\right.$ 100:4). Then the solvent was evaporated in vacuum and the residue obtained was dissolved in $\mathrm{CH}_{2} \mathrm{Cl}_{2}(50 \mathrm{ml})$ and washed with $\mathrm{H}_{2} \mathrm{O}(50$ $\mathrm{ml})$ then dried with sodium sulfate and the solvent was evaporated in vacuum and the residue was dissolved in $\mathrm{CH}_{2} \mathrm{Cl}_{2}(30 \mathrm{ml})$ and 0.1 $\mathrm{ml}$ of hydrazine hydrate was added and the reaction was monitoring by TLC $\left(\mathrm{CH}_{2} \mathrm{Cl}_{2}: \mathrm{MeOH}=100: 1\right)$. After the end of the reaction the reaction mixture was washed by water $(2 \times 10 \mathrm{ml})$, dried with sodium sulfate and the solvent was evaporated in vacuum and the residue was purified by column chromatography (silica gel) with eluent $\mathrm{CH}_{2} \mathrm{Cl}_{2}: \mathrm{MeOH}=100: 1$ to afford $22 \mathrm{mg}(90 \%)$ of the $\mathrm{Ni}(\mathrm{II})$ complex of meso-hydrazone derivative of coproporphyrin I tetraethyl ester (8).

$\mathrm{Ni}(I I)$ complex of meso-hydrazone derivative of coproporphyrin I tetraethyl ester (8). LDI-TOF MS $m / z$ : 864.2. Calcd. for $[\mathrm{M}+\mathrm{H}]^{+}$865.6. UV-Vis $\lambda_{\text {max }}\left(\mathrm{CHCl}_{3}\right) \mathrm{nm}: 400,523,559 .{ }^{1} \mathrm{H} \mathrm{NMR}$ $\left(\mathrm{CDCl}_{3}, 278 \mathrm{~K}\right) \delta_{\mathrm{H}} \mathrm{ppm}: 1.19-1.25\left(9 \mathrm{H}, \mathrm{m}, \mathrm{OCH}_{2} \mathrm{CH}_{3}\right), 1.36(3 \mathrm{H}$, $\left.\mathrm{t},{ }^{3} \mathrm{~J}=7.21, \mathrm{OCH}_{2} \mathrm{CH}_{3}\right), 2.95\left(2 \mathrm{H}, \mathrm{t},{ }^{3} \mathrm{~J}=8.59, \beta-\mathrm{CH}_{2}\right), 3.05(2 \mathrm{H}, \mathrm{t}$, $\left.{ }^{3} J=7.92, \beta-\mathrm{CH}_{2}\right), 3.11-3.14\left(4 \mathrm{H}, \mathrm{m}, \beta-\mathrm{CH}_{2}\right), 3.25\left(3 \mathrm{H}, \mathrm{s}, \beta-\mathrm{CH}_{3}\right)$, $3.42\left(3 \mathrm{H}, \mathrm{s}, \beta-\mathrm{CH}_{3}\right), 3.43\left(3 \mathrm{H}, \mathrm{s}, \beta-\mathrm{CH}_{3}\right), 3.44\left(3 \mathrm{H}, \mathrm{s}, \beta-\mathrm{CH}_{3}\right)$, $4.03-4.06\left(2 \mathrm{H}, \mathrm{m}, \beta-\mathrm{CH}_{2}\right), 4.16-4.23\left(12 \mathrm{H}, \mathrm{m}, \mathrm{OCH}_{2} \mathrm{CH}_{3}+\beta-\mathrm{CH}_{2}\right)$, $4.31\left(2 \mathrm{H}, \mathrm{q},{ }^{3} \mathrm{~J}=7.23, \mathrm{OCH}_{2} \mathrm{CH}_{3}\right), 9.55(1 \mathrm{H}, \mathrm{s}, 15 \mathrm{CH}), 9.58(1 \mathrm{H}, \mathrm{s}$, $20 \mathrm{CH}), 9.59(1 \mathrm{H}, \mathrm{s}, 5 \mathrm{CH}), 9.95(1 \mathrm{H}, \mathrm{s}, \mathrm{CH}=\mathrm{N})$.

\section{X-Ray diffraction study}

Single-crystal X-ray data of 4a were collected by using STOE diffractometer Pilatus $100 \mathrm{~K}$ detector, focusing mirror collimation $\mathrm{CuK}_{\alpha}(1.54086 \AA)$ radiation, rotation method mode. STOE X-AREA software was used for cells refinement and data reduction. Data 
collection and image processing was performed with X-Area 1.67 (STOE \& Cie GmbH, Darmstadt, Germany, 2013). Intensity data were scaled with LANA (part of X-Area) in order to minimize differences of intensities of symmetry-equivalent reflections (multiscan method).

Cell parameters: $a=13.8720(9) \quad \AA, \quad b=16.7480(10) \AA$, $c=18.8310(11) \AA, \alpha=108.132(7)^{\circ}, \beta=108.132(7)^{\circ}, \gamma=103.986(8)^{\circ}$; $V=3899.5(5) \AA^{3}, Z=4, d_{\text {calc }}=1.342$. Crystal class is triclinic, space group P-1.

The crystal structure was solved and refined with SHELX ${ }^{[22]}$ program. The non-hydrogen atoms were refined by using the anisotropic full matrix least-square procedure.

All hydrogen atoms were placed in the calculated positions and allowed to ride on their parent atoms [C-H 0.93-0.98; Uiso $(\mathrm{H})$ $=1.2 \mathrm{Ueq}($ parent atom) $]$.

Refinement was made against 13038 reflections, 998 parameters were refined using 6 restraints. The final $R 0.052$ against 4935 $F^{2}>2 \sigma\left(F^{2}\right), R w=0.119$. Molecular geometry calculations were performed with the SHELX program, and the molecular graphics were prepared by using DIAMOND ${ }^{[23]}$ software.

CCDC-1558823 contain the supplementary crystallographic data for this paper. These data can be obtained free of charge from The Cambridge Crystallographic Data Centre via www.ccdc.cam. ac.uk/data_request/cif.

\section{Results and Discussion}

The goal of this work is the synthesis of meso-functionalized $\mathrm{Ni}$ (II) complexes of $\beta$-octaethylporphyrin and tetraethyl ester of coproporphyrin I. It is known that $\beta$-alkyl substututed meso-functionalized porphyrins and their metal complexes can be easily further transformed ${ }^{[24-27]}$ to compounds with significant bathochromic shift of the absorption bands even up to the nearest IR region. meso-Fuctionalization of porphyrins was carried out using the Vilsmeier-Haack reaction which has a wide application for the introduction of formyl group which can be further transformed to various other functions. ${ }^{[28]}$

Tetraethyl ester of coproporphyrin I and $\beta$-octaethylporphyrin were selected as objects for the modification as they represent two different types of porphyrins with free meso-positions: natural derivative (coproporphyrin) and fully synthetic compound ( $\beta$-octaethylporphyrin). Synthetic $\beta$-octaethylporphyrin is lipophilic, well soluble in organic solvents and often used as a model compound. Coproporphyrin is more hydrophilic due to four carboxyl groups increasing its solubility in aqueous media and its tetraethyl ester is also well soluble in organic solvents. Porphyrins were used in a form of nickel complexes due to the enhanced reactivity of the metal complexes compared to the free bases porphyrins in electrophilic substitution reactions. ${ }^{[8,29]}$ It is also known that nickel complexes are subjected to of VilsmeierHaack formylation with the highest reaction rate. ${ }^{[30]}$

\section{Synthesis}

To obtain $N$-substituted hydrazones of metal complexes of $\beta$-octaethylporphyrin and coproporphyrin I we used a method based on the interaction of meso-formyl derivatives of metal porphyrins with $\mathrm{N}$-substituted hydrazines. meso-Formyl metal porphyrin derivatives were synthesized by formylation with the Vilsmeier-Haack reaction (Scheme 1). Nickel complex of OEP 1 was formylated using Vilsmeier reagent, which was formed by the interaction of $N, N$-dimethylformamide (DMF) with phosphorus(V) oxochloride $\mathrm{POCl}_{3}$ leading to the formation of the so-called "phosphorus complex". [28,31-33]

Next "phosphorus complex" was hydrolyzed with saturated solution of sodium acetate, resulting in nickel complex of the meso-formyl- $\beta$-octaethylporphyrin 2 . It should be noted that the reactions proceeded without the formation of byproducts and target products were obtained with high yields $78-80 \%$.

The next step was the interaction of the nickel complex of meso-formyl- $\beta$-octaethylporphyrin 2 with the corresponding $N$-substituted hydrazines in the presence of trifluoroacetic acid as a catalyst (Scheme 1). From the nickel complex of $\beta$-octaethylporphyrin thus hydrazone derivatives of the following hydrazines were obtained: hydrazine (3), tosylhydrazine (4) and 2,4-dinitrophenylhydrazine (5). ${ }^{1} \mathrm{H}$ NMR of the products contained all peaks confirming their structures. It should be noted that the $N$-substituted hydra-
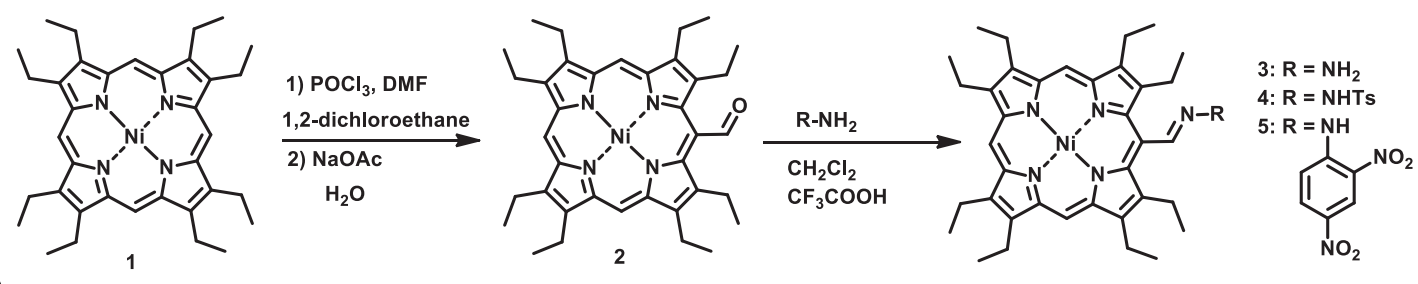

$\mathbf{A}$
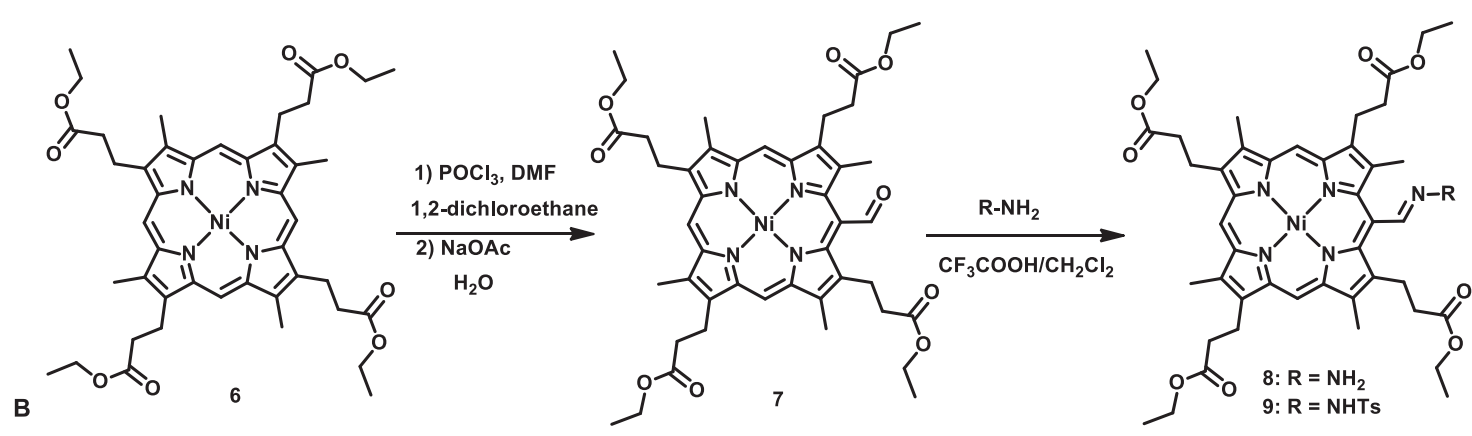

Scheme 1. Synthesis of meso-hydrazones of $\beta$-octaethylporphyrin (A) and tetraethyl ester of coproporphyrin I (B). 
zones were formed as mixtures of $Z, E$-isomers in $4: 1$ ratio according to ${ }^{1} \mathrm{H}$ NMR containing doubling signals of less intensity. Chromatography separation mostly allowed obtaining the major isomers as the minor isomers were transforming to the major ones on the silica. For the tosylhydrazone derivative 4 we succeeded in isolation of the minor $E$-isomer 4b along with the major $Z$-isomer 4 a.

Mass spectra of the hydrazones contain several clusters possessing two major distinctive peaks with a difference of 2 units with a heavier peak of lower intensity. This is typical pattern corresponding to the presence of nickel atom reflecting its isotopic composition. The $m / z$ values are given for the major isotope of nickel (Ni-58). The clusters of the spectra are quite complicated reflecting presence of the products of the transformations of the starting porphyrin leading to additional peaks to the cluster. For example, peaks of lower masses (M-2, M-4) are related to the consequent hydrogen loss from the condensed cycle and ethyl substituents leading to conjugated $\mathrm{C}=\mathrm{C}$ double bonds. Cluster peaks in the mass spectra partially correspond to protonated molecules and ionization of the hydrazones were probably achieved via protonation which could be occur with the help of other molecules of the compound. Thus, the substance in the mass-spectrometer could play a role of the matrix for itself. The most intense cluster is related not to a molecular ion of the product $4(\mathrm{~m} / \mathrm{z} 787.2)$ being the third intensive, but it is the peak of the protonated molecular ion with a mass corresponding to a cyclization product $(\mathrm{m} / \mathrm{z}$ 603.3) (Figure 1). The such cyclization product was not originally present in the reaction mixture. This fact reflects that the condensed cyclopentaneporphyrin could be formed in the conditions of thermolysis of hydrazone porphyrins under laser

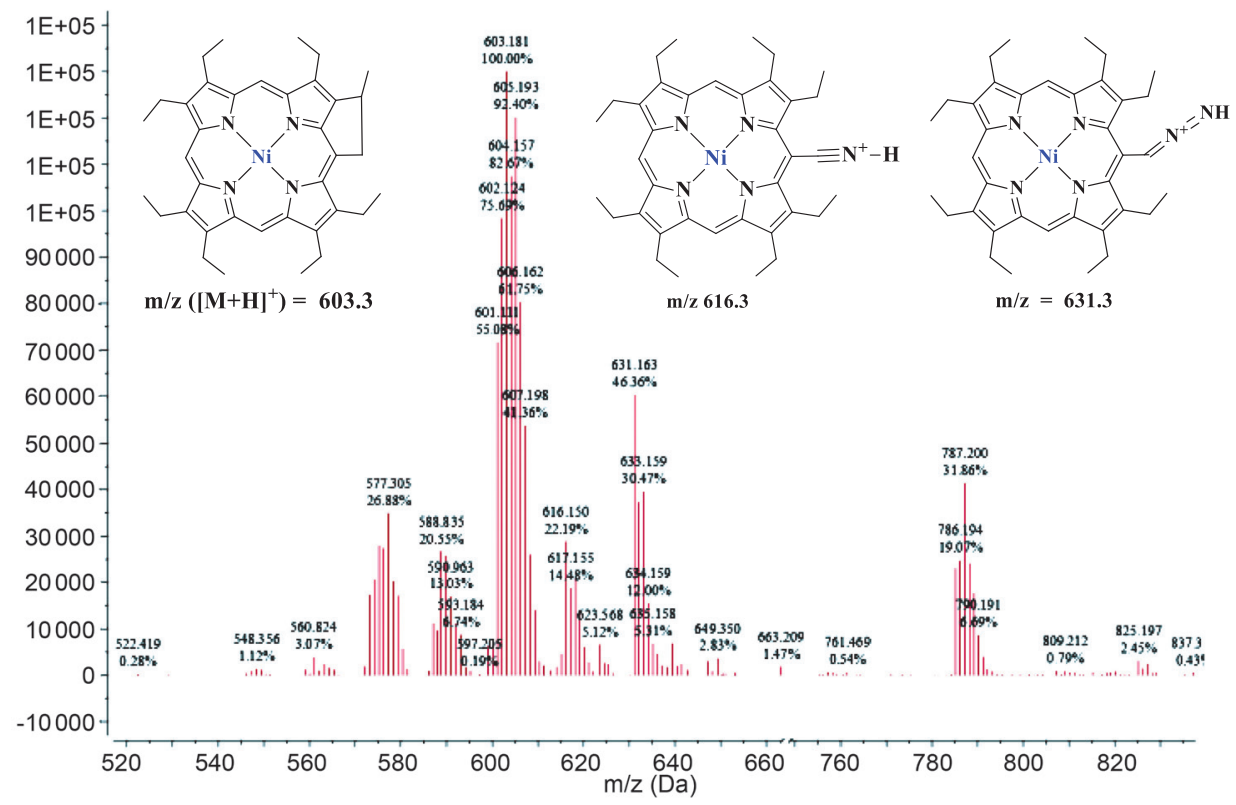

Figure 1. Mass spectrum of $\mathbf{4 a , b}$.

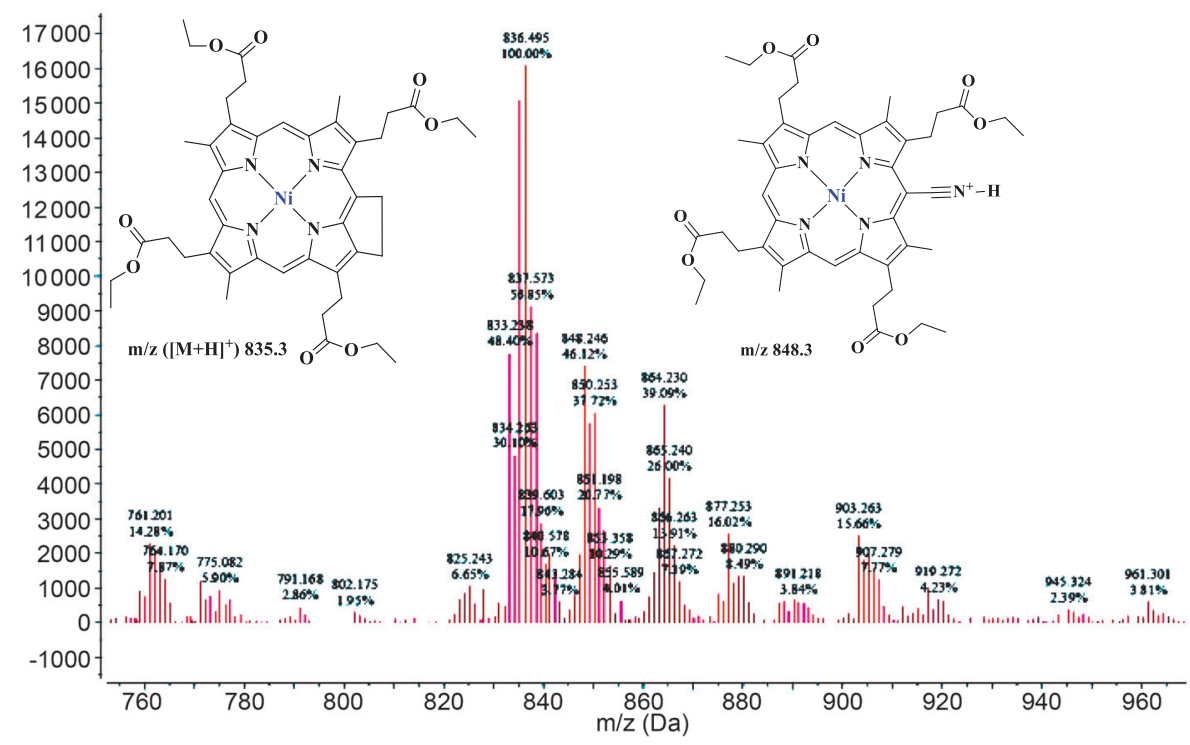

Figure 2. Mass spectrum of $\mathbf{8}$. 
irradiation in the mass-spectrometer similar to the known thermolysis of schiff bases of meso-formylporphyrins. ${ }^{[34-35]}$ The second intense peak belongs to the product or loss of the tosyl group $(\mathrm{m} / \mathrm{z}$ 631.3). Loss of $\mathrm{NH}$ from the latter and (or) loss of TsNH from 4 possibly gave the peak with $m / z 616.15$ corresponding to the protonated nitrile. The condensed cyclopentaneporphyrin $(\mathrm{m} / \mathrm{z}$ 603.3) could also lose acetylene to give a peak 577.3.

Synthesis of hydrazone derivatives of coproporphyrin I was carried out analogously (Scheme 1). Formylation of nickel complex of tetraethyl ester of coproporphyrin I 6 led to the meso-formyl derivative 7 and following reaction with hydrazines gave the corresponding coproporphyrin hydrazones $\mathbf{8}$ and $\mathbf{9}$. The latter was also obtained as the mixture of $Z, E$-isomers $\mathbf{9 a , b}$.

Mass spectrum of compound $\mathbf{8}$ was in main features similar to the compound $\mathbf{4}$ and also contained clusters corresponding to molecular ions of hydrazone $(\mathrm{m} / \mathrm{z} 864.3)$, the cyclopentaneporphyrin $(\mathrm{m} / z$ 835.3) and product of loss of $\mathrm{NH}_{2}$ (protonated nitrile) $(\mathrm{m} / \mathrm{z}$ 848.3) (Figure 2). Therefore, the thermolytic cyclization of porphyrin hydrazones proceeding with different porphyrins is general reaction leading to condensed cyclopentaneporphyrins.

\section{X-Ray diffraction study}

Some hydrazine derivatives of porphyrins were crystallized and the crystal structure was investigated via single crystal X-ray diffraction. X-Ray structure of the major isomer of $\mathbf{4 a}$ is presented at Figure 3. The asymmetric part of the unit cell contains two independent molecules, the atoms of which are designated as NN and NNA (Figure 3 ). In the crystal, the molecules NN and NNA differ from each other. Namely, the direction of methyl groups of ethyl substituents is not the same. In the NN molecule, five methyl groups, among of eight, have the same, as the tosyl fragment, direction with respect to the plane of the porphyrin core. Among the molecules of the NNA, seven methyl groups are located in the same mode as in the NN molecule and only one methyl group $(\mathrm{C} 35 \mathrm{~A} / \mathrm{C} 53 \mathrm{~A})$ is disordered over two positions with the atom occupancy of $0.52 / 0.48$. Porphyrin cores in both molecules exhibit severely distorted saddle-shaped macrocycle conformations. Figure 4 shows the deviation $\left(10^{3} \AA\right)$ of the atoms of the porphyrin in the molecules of NN and NNA from the rms plane drawn through the nitrogen atoms N1-N2-N3-N4 and N1A-N2AN3A-N4A, respectively. The conformation of the porphyrin rings is affected by the interaction of the nickel atom (NN//NNA) with the $\pi$-system of the benzene cycle of the neighboring molecule (NNA//NN) (see Figure 3). The distances between the nickel atom NilA and the carbon atoms $\mathrm{C} 39-\mathrm{C} 44$ lie in the range from 3.707 to 3.787 $\AA$, that is, practically all distances are the same, while the distances between the nickel atoms Nil and C39AC44A differ significantly $-3.517 \AA$ is the shortest distance Ni1-C44A, and $4.180 \AA$ is the largest distance between $\mathrm{Nil}$ and carbons atoms C39A-C44A. In addition, the molecules NN and NNA are linked together by hydrogen bonds N5H5-O1A and N5AH5A-O1, thus, in the crystal, molecules NN and NNA form dimers. The porphyrin ring of $\mathbf{4 a}$ apparently is not flat (Figure 4). This can be partly due to the presence of bulky substituent at meso-position. It should also be noted that the bond lengths of the nickel with all four nitrogens are different.

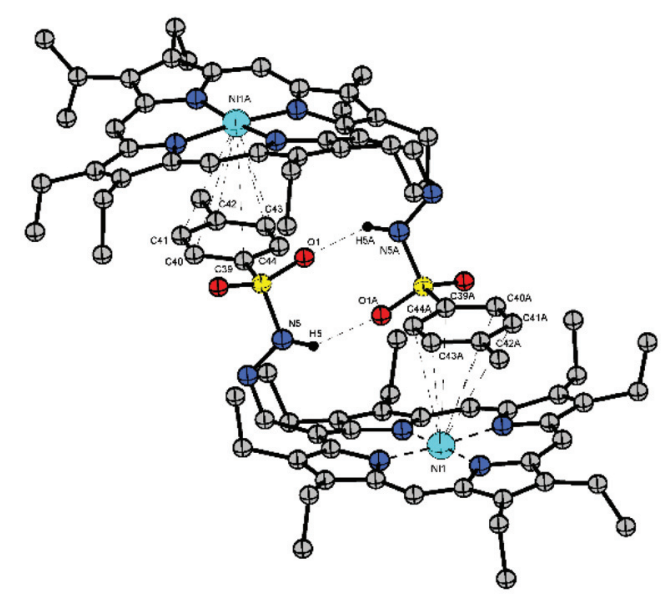

Figure 3. Crystal structure of 4a. The hydrogen atoms (except for hydrogen atoms at nitrogen) are omitted for clarity. Hydrogen and $\pi$-bonds are shown with thin dashed lines. Displacement ellipsoids are drawn at $50 \%$ probability level.
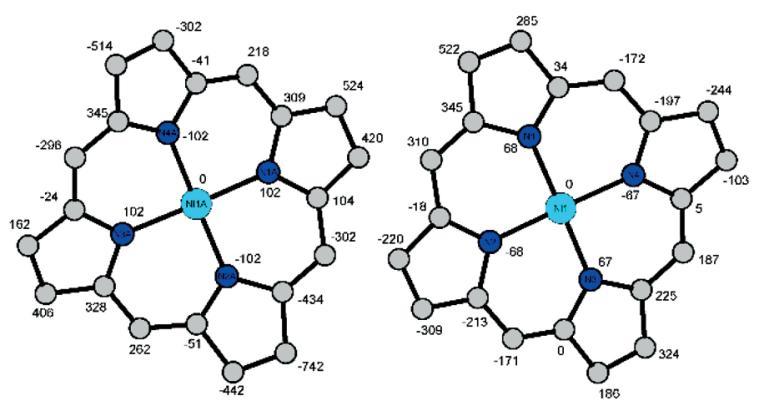

Figure 4. Top view of the two crystallographically independent NN and NNA of Ni(II) porphyrins cores of 4a. Numbers give the deviation of the macrocycle atoms from the least-squares plane of the four nitrogen atoms (in $\AA \cdot 10^{3}$ ).

\section{Conclusions}

The method of meso-functionalization based on mesoformylation following reaction with hydrazine leads to the corresponding meso-hydrazone derivatives of porphyrins. This method was shown to be easy and convenient by the successfully carried out synthesis of $N$-substituted hydrazones of nickel complexes of $\beta$-octaethylporphyrin and tetraethyl ester of coproporphyrin I. Such porphyrins can serve as precursors to various photosensitizers due to the significant influence of the meso-substituents on the electronic absorption spectra allowing to tune photosensitizing properties by variation of meso-substituents. This approach can also be used to obtain porphyrin conjugates with other fragments via further transformations of porphyrins hydrazones. The X-ray study of the crystal structure of the nickel complex of tosyl 
hydrazone derivative of $\beta$-octaethylporphyrin revealed that the porphyrin molecules form dimers bonded by two hydrogen bonds between the hydrogen atom of the NH-group of hydrazone and the oxygen atom of the sulfonate group. Investigations of the further transformation of the hydrazone functional group of the obtained porphyrins to the meso(2-iodvinyl) function are currently in progress.

Acknowledgements. The X-ray part of this study was supported by the Ministry of education and science of the Russian Federation, grant No. RFMEFI61616X0069. The access to STOE diffractometer Pilatus $100 \mathrm{~K}$ was granted by the M.V. Lomonosov Moscow State University Program of Development. The other measurements were performed using equipment of CKP FMI IPCE RAS.

\section{References}

1. Papkovsky D.B., O'Riordan T.S. Journal of Fluorescence 2005, 15, 569-584.

2. Dolphin D. Tetrahedron 1998, 54, 4151-4202.

3. Manivannan E., Yihui C., Penny J., Ravindra K. Chem. Soc. Rev. 2011, 40, 340-362.

4. Liu F., Soh A., Ni Ya., Lim Yi., Mohanram H., Bhattacharjya S., Xing. B. Bioconjugate Chem. 2012, 23, 1639-1647.

5. Tam N.C.M., McVeigh P.Z., MacDonald T.D., Farhadi A., Wilson B.C., Zheng G. Bioconjugate Chem. 2012, 23, 1726-1730.

6. Dosselli R., Gobbo M., Bolognini E., Campestrini S., Reddi E. ACS Med. Chem. Lett. 2010, 1, 35-38.

7. Gianferrara T., Bergamo A., Bratsos I., Milani B., Spagnul C., Sava G., Alessio E. J. Med. Chem. 2010, 53, 4678-4690.

8. Tyurin V.S., Uglov A., Beletskaya I.P., Stern C., Guilard R. Survey of Synthetic Routes for Synthesis and Substitution in Porphyrins. In: Handbook of Porphyrin Science, Vol. 23 (Kadish K.M., Smith K.M., Guilard R., Eds.), Singapore: World Scientific, 2012. p. 81-279.

9. Averin A.D., Yakushev A.A., Beletskaya I.P. Macroheterocycles 2016, 9, 108-120.

10. Hiroto S., Miyake Yo., Shinokubo H. Chem. Rev. 2017, 117, 2910-3043.

11. Volov A.N., Zamilatskov I.A., Mikhel I.S., Erzina D.R., Ponomarev G.V., Koifman O.I., Tsivadze A.Yu. Macroheterocycles 2014, 7, 256-261

12. Tyurin V.S., Erzina D.R., Zamilatskov I.A., Chernyadyev A.Yu., Ponomarev G.V., Yashunskiy D.V., Maksimova A.V., Krasnovskiy A.A., Tsivadze A.Yu. Macroheterocycles 2015, 4, 376-383.
13. Erzina D.R., Zamilatskov I.A., Kurochkina N.M., Ponomarev G.V., Tafeenko V.A. Acta Crystallogr., Sect. C: Cryst. Struct. Commun. 2017, 73(2), 68-71.

14. Andreev S.V., Zverev S.A., Zamilatskov I.A., Kurochkina N.M., Ponomarev G.V., Fitch A.N., Chernyshev V.V. Acta Crystallogr., Sect. C: Cryst. Struct. Commun. 2017, 73(1), 47-51.

15. Zverev S.A., Andreev S.V., Zamilatskov I.A., Kurochkina N.M., Tyurin V.S., Senchikhin I.N., Ponomarev G.V., Erzina D.R., Chernyshev V.V. Russ. J. Phys. Chem. A 2017, 91, 1462 1467.

16. Lonin I.S., Belyaev E.S., Tsivadze A.Yu., Ponomarev G.V., Lonina N.N., Fitch A.N., Chernyshev V.V. Macroheterocycles 2017, 10, 474-479.

17. Shastin A.V., Korotchenko V.N., Varseev G.N., Nenaidenko V.G., Balenkova E.S. Russ. J. Org. Chem. 2003, 39, 403-407.

18. Smith K.M. J. Chem. Soc., Perkin Trans. 1 1972, 1471-1475.

19. Sessler J.L., Mozaffari A., Johnson M.R. Org. Synth. 1992, 70, $68-75$.

20. Shelnutt J.A., Medforth C.J., Berber M.D., Barkigia K.M., Smith K.M. J. Am. Chem. Soc. 1991, 113, 4077-4087.

21. Arnold D., Johnson A.W., Winter M. J. Chem. Soc., Perkin Trans. 1 1977, 1643-1647.

22. Sheldrick G.M. Acta Crystallogr., Sect. A: Found. Crystallogr. 2008, $A 64,112-122$.

23. Brandenburg K. DIAMOND, Release 2.1d; Crystal Impact GbR: Bonn, Germany, 2000.

24. Inhoffen H.H., Fuhrhof J.-H., Voigt H., Brockmann H. Liebigs Ann. Chem. 1966, 695, 133-143.

25. Brockmann Jr. H., Bliesener K., Inhoffen H.H. Liebigs Ann. Chem. 1968, 718, 148-161.

26. Ponomarev G.V., Evstigneeva R.P., Preobrazhenskiy N.A. Chem. Heterocycl. Compd. 1967, 3, 303.

27. Torpey J.W., Montellano P.R.O. J. Org. Chem. 1996, 60, $2195-$ 2199.

28. Ponomarev G.V. Chem. Heterocycl. Compd. 1994, 30, 1444 1465.

29. Schlozer R., Fuhrhop J.-H. Angew. Chem. Int. Ed. 1975, 14, 363.

30. Buchler J.W., Dreher C., Herget G. Liebigs Ann. Chem. 1988, $43-54$.

31. Ponomarev G.V., Evstigneeva R.P., Stromnov V.N., Preobrazhenskii N.A. Chem. Heterocycl. Compd. 1967, 2, 479-480.

32. Ponomarev G.V. Chem. Heterocycl. Compd. 1996, 32, 1263 1280.

33. Ponomarev G.V., Yashunskiy D.V., Moskovkin A.S. Chem. Heterocycl. Compd. 1997, 33, 271-275.

34. Ponomarev G.V., Shul'ga A.M. Chem. Heterocycl. Compd. 1984, 20, 383-388.

35. Ponomarev G.V., Shul'ga A.M., Rozynov B.V. Chem. Heterocycl. Compd. 1993, 29, 155-162. 